\title{
CLINICAL VALUE OF TRANSVAGINAL ULTRASONOGRAPHY IN COMPARISON TO HYSTEROSCOPY WITH HISTOPATHOLOGIC EXAMINATION IN DIAGNOSING ENDOMETRIAL ABNORMALITIES
}

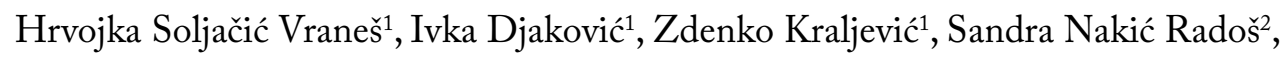 \\ Tanja Leniček ${ }^{3}$ and Krunoslav Kuna ${ }^{1}$
}

\begin{abstract}
${ }^{1}$ Department of Gynecology and Obstetrics, Sestre milosrdnice University Hospital Centre, Zagreb, Croatia; ${ }^{2}$ Department of Psychology, Catholic University of Croatia, Zagreb, Croatia;

${ }^{3}$ Ljudevit Jurak University Department of Pathology, Sestre milosrdnice University Hospital Centre, Zagreb, Croatia
\end{abstract}

\begin{abstract}
SUMMARY - The aim of our retrospective study was to compare the performance of transvaginal sonography in relation to histologic diagnosis of samples obtained by hysteroscopy through analysis of data collected over 16 years. Data on suspected formation of endometrial polyp or submucosal fibroid found on ultrasound examination were extracted. The study included a total of 3679 women examined during the 2000-2015 period. All women underwent ultrasound examination preoperatively for better planning the type and scope of operation to be performed. The study included only women with samples for histopathologic analysis collected during the operation. Ultrasound diagnosis of polyps compared with histology showed $89.6 \%$ sensitivity and $39.1 \%$ specificity. For submucosal myomas, sensitivity was $69.2 \%$ and specificity $91.3 \%$. In conclusion, ultrasound is not reliable method for definitive diagnosis but it is an excellent orientation method.
\end{abstract}

Key words: Hysteroscopy; Polyps; Ultrasonography; Retrospective studies; Uterine neoplasms; Leiomyoma

\section{Introduction}

Ultrasound has been in use for more than 60 years and nowadays it is the method of choice in uterine pathology evaluation. Transvaginal ultrasound has many advantages in practice. Proximity of tested areas enables high image quality and sharp picture of gynecologic structures. Additional benefits of the method are acquired by pulsed Doppler enabling insight into blood supply of the structures observed. This provides better assessment of normal and pathological structures.

Correspondence to: Ivka Djakovic, $M D$, Department of Gynecology and Obstetrics, Sestre milosrdnice University Hospital Centre, Vinogradska c. 29, HR-10000 Zagreb, Croatia

E-mail: ivkadj@yahoo.com

Received May 2, 2018, accepted September 11, 2018
Uterine myomas are the most common tumors in women of reproductive age ${ }^{1}$. Myomas appear as echoic or hypoechoic nodules on ultrasound examination. If there are secondary changes in myomas, such as necrosis, calcification, hemorrhage, etc., ultrasound imaging will not be specific. If these secondary changes are located submucosally, differential diagnosis may be difficult because some other uterine changes look alike, i.e. polyps, hyperplasia, blood, mucus, etc. The use of color and pulsed Doppler can differentiate these changes more confidently, although in case of secondary changes such as necrosis or inflammation, low resistance index (RI) can be found as in malignancy ${ }^{2}$.

Endometrial polyps appear as focal or diffuse changes in the uterine lining on ultrasound examination. The easiest visualization of polyps is achieved 
when the endometrium is thinnest, that is, immediately after menstrual bleeding in premenopausal women. Endometrial polyp can also be modified by secondary inflammation or necrosis. Examination during menstruation when fluid is present in the uterus or after instillation of contrast into the uterine cavity facilitates visualization of polyps and discernment to the thickened endometrium.

Hysteroscopy dates before ultrasound. The first diagnostic and therapeutic hysteroscopy was performed in the $19^{\text {th }}$ century by Desormeaux ${ }^{3}$, when hysteroscopic endometrial polyp was treated with silver nitrate. Diagnostic hysteroscopy is used for visualization of the endocervical canal, endometrial cavity and tubal estuary. Operative hysteroscopy involves the use of mechanical, electrosurgical or laser instruments in the treatment of intracavitary pathology.

Hysteroscopy is now a widespread method in the diagnosis and treatment of endometrial abnormalities. The most common complications of hysteroscopic surgery include complications related to anesthesia and analgesia, excessive absorption of ionic liquids, perforation of the uterus, and injury of the surrounding structures. When the monopolar resectoscope is used, thermal injury to the vulva and vagina is possible ${ }^{4}$.

The aim of our retrospective study with 16-year data was to compare the performance of transvaginal sonography in relation to histologic diagnosis of samples obtained by hysteroscopy. Data on suspected formation of endometrial polyp or submucosal myomas found on ultrasound examination were extracted.

\section{Patients and Methods}

The study included a total of 3679 women examined during the 2000-2015 period at Sestre milosrdnice University Hospital Centre. All women were admitted for planned hysteroscopic surgery and underwent preoperative ultrasound examination for better planning the type and scope of the operation to be performed. Ultrasound is used to diagnose the presence of myomas or polyps. Endometrial polyps may be visualized on transvaginal ultrasound as nonspecific endometrial thickening or may be identified as focal masses within the endometrium. They can be hypoechoic, isoechoic or echogenic compared to the adjacent myometrium. Leiomyomas are usually well-defined, solid masses. Their echogenicity is usually simi- lar to that of the myometrium, but sometimes they are hypoechoic or even hyperechoic compared to normal myometrium. They can have calcifications or necrosis. Calcifications are seen as echogenic foci with shadowing, and cystic areas may be seen if there is necrosis or degenerations.

The study included only women with samples for histopathologic analysis collected during the operation. Patients were analyzed in two groups: polyp group and myoma group. Study groups were tested for anthropologic characteristics such as age, menopausal status, marital status and place of residence.

We used $\chi^{2}$-test to determine the significance of differences in frequency between the groups. ANOVA (analysis of variance) was used to determine the significance of differences in patient age according to diagnosis and test period. When necessary, post-hoc Tukey HSD test was applied to determine differences among the groups. Online VassarStats calculator (http://www.vassarstats.net/) was used to determine sensitivity and specificity of a particular diagnostic test. The level of significance was set at $\mathrm{p}<0.05$ in all tests.

\section{Results}

The number of hysteroscopy procedures increased continuously during the study period $\left(\chi^{2}(15, \mathrm{~N}=3679)=\right.$ 2331.51, $\mathrm{p}<0.001$ ).

The most common referral diagnoses were polyps and myomas. The incidence of polyps and myomas significantly increased in the $2000-2015$ period $\left(\chi^{2}\right.$ $(15, \mathrm{~N}=2945)=1871.34$ and $\chi^{2}(15, \mathrm{~N}=525)=222.18$, respectively; $\mathrm{p}<0.001$ both).

The most common types of operation performed were ablation of polyp and ablation of myoma. The overall number of polyp ablations and myoma ablations significantly increased in the $2000-2015$ period $\left(\chi^{2}(15, \mathrm{~N}=2487)=1468.40\right.$ and $\chi^{2}(15, \mathrm{~N}=525)=233.44$, respectively; $\mathrm{p}<0.001$ both) (Fig. 1 ).

The most common histologic findings were polyps, myomas and normal endometrium, as illustrated in Figure 2 . The number of polyps significantly increased in the 2000-2015 period $\left(\chi^{2}(15, \mathrm{~N}=2453)=2065.51\right.$; $\mathrm{p}<0.001)$. The incidence of myomas and normal endometrium $\left(\chi^{2}(15, \mathrm{~N}=341)=259.54\right.$ and $\chi^{2}(15, \mathrm{~N}=630)=$ $636.99, \mathrm{p}<0.001$ both) was significantly changed in the 2000-2015 period. 


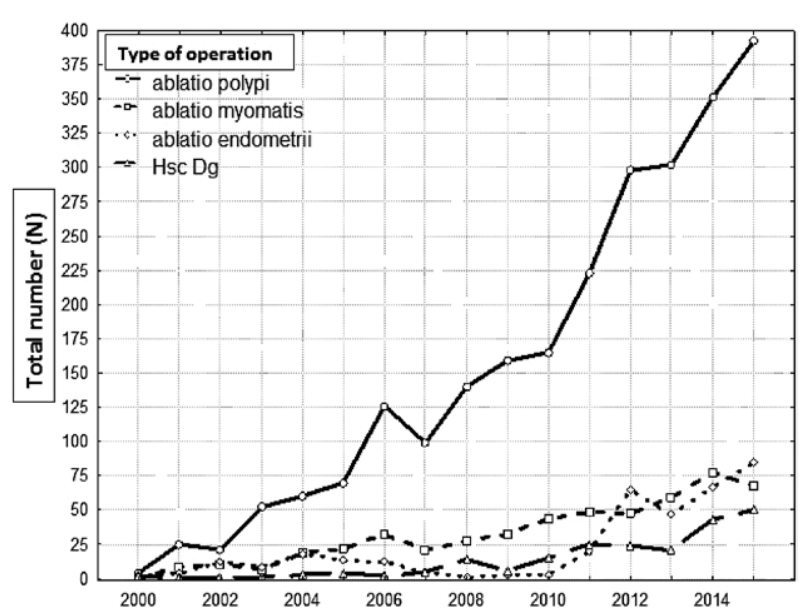

Fig. 1. Types of operation during the 2000-2015 period.

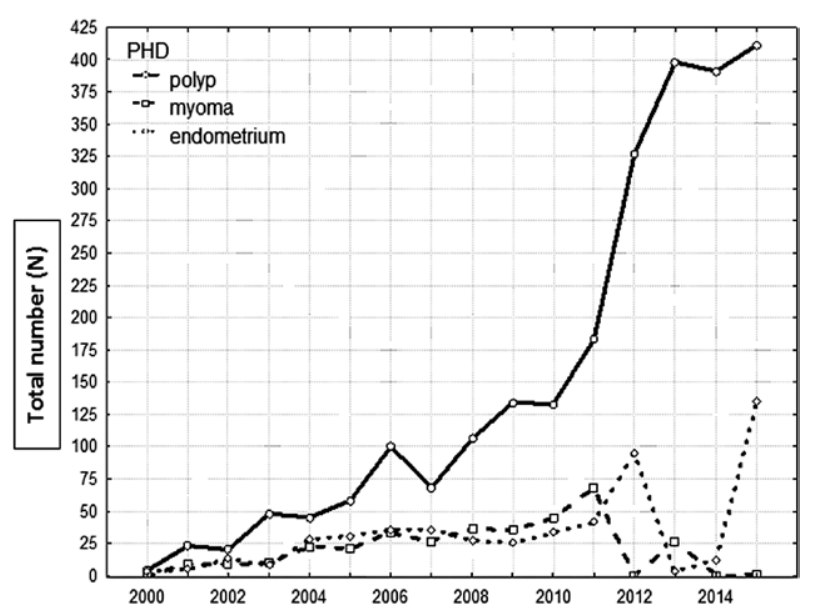

Fig. 2. Histopathologic findings during the 2000-2015 period.

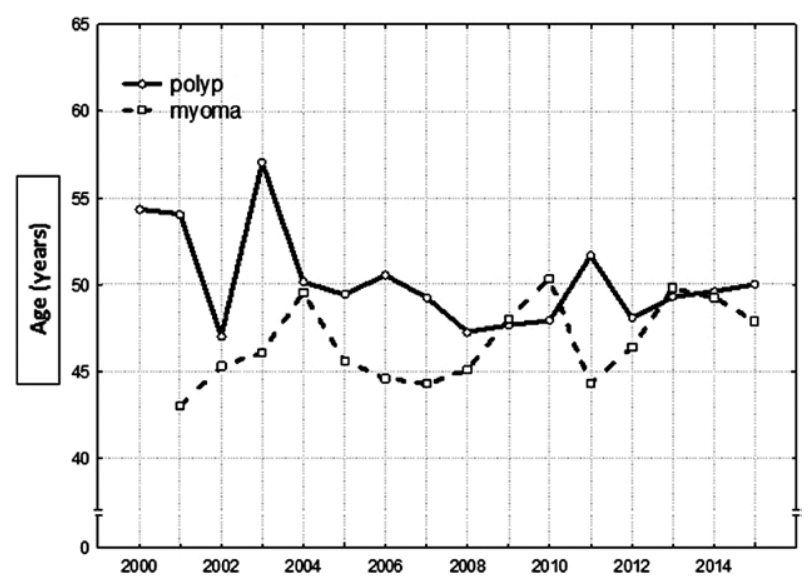

Fig. 3. Age of women with polyps and myomas during the 2000-2015 period.
Significant correlation was found between the mean age and the diagnosis of polyps and fibroids. During the 2000-2015 period, the age of women diagnosed with polyps decreased by about 5 years, while the age of women diagnosed with myomas increased by about 4 years $(F(14,2956)=1.74 ; p<0.05)$, (Fig. 3).

Although there were more married women $\left(\chi^{2}\right.$ $(3 \mathrm{M}=2895)=24.07 ; \mathrm{p}<0.01)$, the groups did not differ according to marital status (Table 1). Menopausal women had the same incidence of polyps, but significantly fewer myomas $\left(\chi^{2}(1, N=2795)=36.25 ; p<0.001\right)$ (Table 2). The incidence of myomas and polyps was the same in women from urban and rural areas $\left(\chi^{2}(1\right.$, $\mathrm{N}=2795)=0.17 ; \mathrm{p}>0.05)$ (Table 3 ).

A total of 2945 women were prediagnosed with polyps. In 2199 of them, diagnosis was confirmed by histopathology (Table 4). In addition, histopathology confirmed the diagnosis of polyps in 254 of 733 wom-

Table 1. Number of women with polyps or myomas according to marital status

\begin{tabular}{|l|l|l|}
\hline & $\begin{array}{l}\text { Polyp } \\
\mathrm{n}(\%)\end{array}$ & $\begin{array}{l}\text { Myoma } \\
\mathrm{n}(\%)\end{array}$ \\
\hline Married & $1775(72.3)$ & $249(73.0)$ \\
Single & $325(13.2)$ & $54(15.8)$ \\
Divorced & $87(3.5)$ & $19(5.6)$ \\
Widow & $267(11.0)$ & $19(5.6)$ \\
\hline Total & 2454 & 341 \\
\hline
\end{tabular}

Table 2. Number of women with polyps or myomas according to menopausal status

\begin{tabular}{|l|l|l|l|}
\hline & & $\begin{array}{l}\text { Polyp } \\
\text { n (\%) }\end{array}$ & $\begin{array}{l}\text { Myoma } \\
\text { n (\%) }\end{array}$ \\
\hline \multirow{2}{*}{ Menopause } & Yes & $1178(48.0)$ & $104(31.7)$ \\
& No & $1276(52.0)$ & $237(68.3)$ \\
\hline & Total & 2454 & 341 \\
\hline
\end{tabular}

Table 3. Number of women with polyps or myomas according to residence

\begin{tabular}{|l|l|l|l|}
\hline & & $\begin{array}{l}\text { Polyp } \\
\text { n (\%) }\end{array}$ & $\begin{array}{l}\text { Myoma } \\
\text { n (\%) }\end{array}$ \\
\hline Residence & Rural & $746(30.4)$ & $108(31.7)$ \\
& Urban & $1708(69.6)$ & $233(68.3)$ \\
\hline & Total & 2454 & 341 \\
\hline
\end{tabular}


Table 4. Frequency of polyp prediagnosis compared to definitive histopathology

\begin{tabular}{|l|l|l|l|l|}
\hline \multicolumn{2}{|l|}{} & \multicolumn{2}{|l|}{$\begin{array}{l}\text { Definitive } \\
\text { histopathology }\end{array}$} & \multirow{2}{*}{ Total } \\
\cline { 3 - 4 } \multicolumn{2}{|l|}{} & Other & Polyp & \\
\hline \multirow{2}{*}{ Prediagnosis } & Polyp & 746 & 2199 & 2945 \\
& Other & 479 & 254 & 733 \\
\hline & Total & 1225 & 2453 & 3678 \\
\hline
\end{tabular}

Table 5. Metrical characteristics of definitive histopathology compared to polyp prediagnosis

\begin{tabular}{|l|l|l|l|}
\hline & \multirow{2}{*}{ Value } & \multicolumn{2}{|l|}{$95 \%$ confidence interval } \\
\cline { 3 - 4 } & & Lower limit & Upper limit \\
\hline Prevalence & 0.667 & 0.651 & 0.682 \\
Sensitivity & 0.896 & 0.884 & 0.908 \\
Specificity & 0.391 & 0.363 & 0.419 \\
False-positive & 0.252 & 0.238 & 0.270 \\
False-negative & 0.347 & 0.312 & 0.382 \\
\hline
\end{tabular}

Table 6. Frequency of myoma prediagnosis compared to definitive histopathology

\begin{tabular}{|l|l|l|l|l|}
\hline \multicolumn{2}{|l|}{} & \multicolumn{2}{|l|}{$\begin{array}{l}\text { Definitive } \\
\text { histopathology }\end{array}$} & \multirow{2}{*}{ Total } \\
\cline { 3 - 5 } \multicolumn{2}{|l|}{} & Other & Myoma & \\
\hline \multirow{2}{*}{ Prediagnosis } & Myoma & 289 & 236 & 525 \\
& Other & 3048 & 105 & 3153 \\
\hline & Total & 3337 & 341 & 3678 \\
\hline
\end{tabular}

Table 7. Metrical characteristics of definitive histopathology compared to myoma prediagnosis

\begin{tabular}{|l|l|l|l|}
\hline & \multirow{2}{*}{ Value } & \multicolumn{2}{|l|}{$95 \%$ confidence interval } \\
\cline { 3 - 4 } & & Lower limit & Upper limit \\
\hline Prevalence & 0.093 & 0.083 & 0.103 \\
Sensitivity & 0.692 & 0.640 & 0.740 \\
Specificity & 0.913 & 0.903 & 0.923 \\
False-positive & 0.550 & 0.507 & 0.593 \\
False-negative & 0.033 & 0.027 & 0.040 \\
\hline
\end{tabular}

en with another referral diagnosis. The sensitivity and specificty for referral diagnosis was $89.6 \%$ and $39.1 \%$, respectively (Table 5).

A total of 525 women were prediagnosed with myomas. In 236 of them, the diagnosis was confirmed by histopathology (Table 6). In addition, histopathology confirmed the diagnosis of myomas in 105 of 3153 women with another referral diagnosis. The sensitivity and specificty for referral diagnosis was $69.2 \%$ and 91.3\%, respectively (Table 7).

\section{Discussion}

Ultrasound is a widespread method that has evolved through sophisticated programs and devices. However, $2 \mathrm{D}$ ultrasound is still the most used method ${ }^{5}$. Ultrasound examination is simple, fast, noninvasive and easy to learn, with no side effects, while providing additional information to physical examination. In modern gynecologic routine, ultrasound is irreplaceable.

First attempts at constructing instruments for visualization of intrauterine pathology date back to 1805 when Binzzini constructed a series of concave mirrors to visualize uterine cavity ${ }^{6}$. First hysteroscopy was performed in $1869^{3}$. Since then, the procedure has been greatly improved, so that most patients are not hospitalized, even in case of therapeutic procedure ${ }^{7}$.

Complications of hysteroscopy are rare and more often due to therapeutic procedure ${ }^{8}$. Hysteroscopy is used for a wide range of diagnostic and therapeutic algorithms, e.g., assessment of sterility, recurrent miscarriage, uterine anomalies, and diagnosis and treatment of endometrial pathology ${ }^{9-11}$. In the last fifteen years, hysteroscopy has been used more frequently for a wide spectrum of indications. Ultrasound is mostly used for detection of suitable cases and proper indications. A1though most studies state that endometrial polyps are symptomatic, there are questions of the frequency of hysteroscopy and possibility of ultrasound follow up ${ }^{12,13}$. The most common diagnoses in hysteroscopy candidates are endometrial polyps and submucosal myomas ${ }^{14}$, as well as histology findings ${ }^{15}$, as in our study.

Treatment of endometrial polyps and endometrial thickness in postmenopausal women differs. The former should always be treated operatively, whereas the latter require only follow up but the diagnosis is not always possible by ultrasound ${ }^{16,17}$. So, the diagnosis should be definitive before making this decision. Like other authors ${ }^{18-20}$, we compared the accuracy of ultrasound diagnosis in 3679 patients.

In our study, the sensitivity and specificity of ultrasound diagnosis of polyps compared with histology was $89.6 \%$ and $39.1 \%$, respectively. For submucosal myomas, sensitivity was $69.2 \%$ and specificity $91.3 \%$, 
suggesting a conclusion that ultrasound is not reliable method for definitive diagnosis but is an excellent orientation method.

Myomas in postmenopausal women are usually asymptomatic and often not treated operatively. However, in premenopausal women, myomas often cause symptoms such as prolonged and heavy bleeding due to cavum deformities, and should be treated operatively.

In premenopausal women without the risk of endometrial hyperplasia or cancer (obesity, Lynch syndrome, polycystic ovary syndrome), polyps can only be followed up if asymptomatic, whereas in postmenopausal women, the risk of malignancy in polyps is higher and hysteroscopic diagnosis and histopathologic verification is recommended ${ }^{21}$.

In conclusion, ultrasound is not reliable method for definitive diagnosis of polyps and myomas but is an excellent orientation method.

\section{References}

1. Fleischer AC, Entman SS, Porrath SA, James AE. Sonographic evaluation of uterine malformations and disorders. In: Sanders RC, ed. The Principles and Practice of Ultrasonography in Obstetrics and Gynecology. Norwalk: Appleton Century Crofts, 1985: p. 531-45.

2. Kurjak A, Kupešić S, Mirić D. The assessment of benign uterine tumor vascularisation by transvaginal color Doppler. J Ultrasound Med Biol. 1992;6:645-9.

http://dx.doi.org/10.1016/0301-5629(92)90079-P

3. Pantaleoni DC. On endoscopic examination of the cavity of the womb. Med Press Circ. 1869;8:26-7.

4. Munro MG, Christianson LA. Complications of hysteroscopic and uterine resectoscopic surgery. Clin Obstet Gynecol. 2015;58(4):765-97.

http://dx.doi.org/10.1097/GRF.0000000000000146

5. Stadtmauer L, Shah A. Gynecologic surgery: preoperative assessment with ultrasound. Clin Obstet Gynecol. 2017;60(1): 82-92. http://dx.doi.org/10.1097/GRF.0000000000000260

6. Lindeman HJ. The hysteroscopy. In: Van der Pas H, Vancaillie T, eds. Manual of Hysteroscopy. Amsterdam-New York-Oxford: Elsevier Science Publishers B.V., 1990; p. 9-12.

7. Dealberti D, Riboni F, Prigione S, Pisani C, Rovetta E, Montella F, Garuti G. New mini-resectoscope: analysis of preliminary quality results in outpatient hysteroscopic polypectomy. Arch Gynecol Obstet. 2013;288(2):349-53. http://dx.doi. org/10.1007/s00404-013-2754-7

8. Cooper JM, Brady RM. Intraoperative and early postoperative complications of operative hyseroscopy. Obstet Gynecol Clin North Am. 2000;27:347-66.

9. El-Matny A, Abou-Salem N, El-Sherbiny W, Saber W. Outpatient hysteroscopy: a routine investigation before assisted reproductive techniques? Fertil Steril. 2011;95:272-6. http:// dx.doi.org/ 10.1016/j.fertnstert.2010.06.033

10. Zolghardi J, Momtahan M, Aminian K, Ghaffarpasand F, Tavana $Z$. The value of hysteroscopy in diagnosis of chronic endometritis in patients with unexplained recurrent spontaneous abortion. Eur J Obstet Gynecol Reprod Biol. 2011;155:217-20. http://dx.doi.org/10.1016/j.ejogrb.2010.12.010

11. Dendrinos S, Grigoriou O, Sakkas EG, Makrakis E, Creatsas G. Hysteroscopy in the evaluation of habitual abortions. Eur J Contracept Reprod Health Care. 2008;13:198-200. http:// dx.doi.org/10.1080/13625180801920032

12. Haimov-Kochman R, Deri-Hasid R, Hamani Y, Voss E. The natural course of endometrial polyps: could they vanish when left untreated? Fertil Steril. 2009;92:828. http://dx.doi.org/10.1016/j.fertnstert.2009.04.054

13. Lieng M, Istre O, Sandvik L, Qvigstad E. Prevalence, 1-year regression rate, and clinical significance of asymptomatic endometrial polyps: cross-sectional study. J Minim Invasive Gynecol. 2009;16:465-71.

http://dx.doi.org/10.1016/j.jmig.2009.04.005

14. Aslam M, Ijaz L, Tariq S, Shafqat K, Meher-Un-Nisa, Ashraf $\mathrm{R}$, Kazmi T. Comparison of transvaginal sonography and saline contrast sonohysterography in women with abnormal uterine bleeding: correlation with hysteroscopy and histopathology. Int J Health Sci. 2007;1:17-24.

15. Kalampokas T, Gregoriou O, Grigoriadis C, Iavazzo C, Zervakis A, Sofoudis C, Kalampokas E, Botsis D. Comparing transvaginally defined endometrial thickness with hysteroscopic and histopathologic findings in asymptomatic postmenopausal women. Eur J Gynaecol Oncol. 2012;33:508-11.

16. Goldstein SR. Significance of incidentally thick endometrial echo on transvaginal ultrasound in postmenopausal women. Menopause. 2011;18:434-6. http://dx.doi.org/ 10.1097/gme.0b013e31820ad00b

17. Lieng M, Qvigstad E, Sandvik L, Jorgensen H, Langebrekke A, Istre O. Hysteroscopic resection of symptomatic and asymptomatic endometrial polyps. J Minim Invasive Gynecol. 2007; 14:189-94. http://dx.doi.org/10.1016/j.jmig.2006.09.018

18. Yantapant A. Comparison of the accuracy of transvaginal sonography and hysteroscopy for the diagnosis of endometrial polyps at Rajavithi Hospital. J Med Assoc Thai. 2012;95 Suppl 3:S92-7.

19. Kasraeian M, Asadi N, GhaffarpasandF, Karimi AA. Value of transvaginal ultrasonography in endometrial evaluation of non-bleeding postmenopausal women. Climacteric. 2011;14: 126-31. http://dx.doi.org/10.3109/13697137.2010.514079

20. La Sala GB, Blasi I, Gallinelli A, Debbi C, Lopopolo G, Vinci V, Villani MT, Iannotti F. Diagnostic accuracy of sonohysterography and transvaginal sonography as compared with hysteroscopy and endometrial biopsy: a prospective study. Minerva Ginecol. 2011;63:421-7.

21. Lieng M, Istre O, Qvigstad E. Treatment of endometrial polyps: a systematic review. Acta Obstet Gynecol Scand. 2010;89(8): 992-1002. http://dx.doi.org/10.3109/00016349.2010.493196 
Sažetak

\section{KLINIČKA VRIJEDNOST TRANSVAGINALNE ULTRASONOGRAFIJE U USPOREDBI S HISTEROSKOPIJOM I HISTOPATOLOŠKOM ANALIZOM KOD DIJAGNOZE ENDOMETRALNIH ABNORMALNOSTI}

\section{H. Soljačić Vraneš, I. Djaković, Z. Kraljević, S. Nakić Radoš, T. Leniček i K. Kuna}

Cilj ovog retrospektivnog istraživanja je bila usporedba pouzdanosti transvaginalnog ultrazvuka u odnosu na histološki nalaz dobiven histeroskopijom kroz analizu podataka skupljenih tijekom 16 godina. Podatci o suspektnim endometralnim polipima i submukoznim miomima primijećenim na ultrazvučnom pregledu su izdvojeni. U istraživanje je uključeno 3679 žena pregledanih u razdoblju od 2000. do 2015. godine. Svim ženama je učinjen prijeoperacijski ultrazvučni pregled radi planiranja tipa i opsega zahvata. U istraživanje su uključene samo žene kojima je uzet histološki uzorak tijekom operacije. Ultrazvučno utvrđeni polipi u usporedbi s histološkim nalazom pokazali su osjetljivost od $89,6 \%$ i specifičnost od $39,1 \%$. Za submukozne miome utvrđena je osjetljivost od 69,2\% i specifičnost od 91,3\%. Može se zaključiti kako je ultrazvuk nepouzdana metoda pri donošenju konačne dijagnoze, ali odlična orijentacijska metoda.

Ključne riječi: Histeroskopija; Polipi; Ultrazvuk; Retrospektivne studije; Uterus, tumori; Leiomiomi 